Research Article

\title{
Determination of Akbash Shepherd Dog raised in Turkey
}

\author{
Orhan Yılmaz a, *, Mehmet Ertuğrul b \\ a Iğdır University, Faculty of Agriculture, Department of Animal Science, 76000 Iğdır-Turkey \\ ${ }^{b}$ Ankara University, Faculty of Agriculture, Department of Animal Science, 06110 Ankara-Turkey \\ * Corresponding author: zileliorhan@gmail.com
}

\begin{abstract}
This study was carried out to determine the body measurements of the Turkish Akbash Shepherd Dogs raised in provinces of Afyon, Ankara, Eskisehir and Manisa by comparing with some other dog breeds of Turkey by minding factors of sex, region and age. For this purpose, a total of 59 (34 male and 25 female) dogs was included in the study and the data were statistically analysed. Descriptive statistics and comparison results for live weight $44.9 \pm 0.80 \mathrm{~kg}$, and height at shoulders $75.3 \pm 0.59$, height at rump 74.2 \pm 0.64 , body length $81.8 \pm 1.00$, heart girth circumference $86.5 \pm 0.81$, chest width $32.6 \pm 0.33$, and cannon circumference $13.3 \pm 0.13 \mathrm{~cm}$ respectively. The overall results of the study showed that Turkish Akbash Shepherd dogs had a very close resemblance to the Turkish Kangal (Karabash) and Kars (Caucasian) Shepherd dogs related with body measurements. The Akbash Shepherd dogs reach mature body weight and size at around 2 years of age. The current study also demonstrated that the Turkish Akbash Shepherd dogs raised in provinces of Afyon and Manisa are smaller than dogs raised in Ankara and Eskisehir.
\end{abstract}

Keywords: Akbash, native dog breed, phenotypic trait, live weight, body measurement

\section{Introduction}

The dog is the first domesticated animal in prehistoric times but there is no full agreement on where and when dogs (Canis familiaris) originated (Clutton-Brock 1995; Serpell 1996). A genetic evidence for East Asian origin of domestic dog was found in China about 15.000 years ago (Savolainen et al. 2002). In Turkey, Belli (2006) reported that hunting seen with dog about 15.000 years ago rock carving in village of Calli, county of Kagizman, province of Kars, Turkey. Belli revealed that the rock carving showed that dogs used to use to hunt deer and/or wild goats in ancient times (Yilmaz 2007a).

There are more than 400 dog breeds in the world and this number increases every year (Pugnetti 2011). Among the dog species livestock protection dogs are bred to defend people and their possessions (Yilmaz 2006). They are generally large, rugged and impressive in body size. They possess great endurance and agility. The livestock protection dogs are tall and powerful, yet not massive in build. This magnificent ancient working dog presents an impression of functional utility without exaggerated features. Large size is important, but correct breed type, soundness of movement, overall balance with correct temperament should be given precedence so as to preserve working ability. Flock guardian dogs show an alert, territorial and protective temperament of sheep and goats and their human family. Their possessive natural protective instinct is calm, noble, courageous, steady, intelligent, sensitive and affectionate with its own family and flock, loyal, proud, self-assured and independent. (Sims \& Dawydiak 1990; Yilmaz 2006).
In Turkey there are about 10 native dog breeds. One of them is a common and others are local breeds listed in Table 1. Three of 10 dog breeds are livestock guardian dogs. The Turkish Kangal (Karabash) Shepherd (TKnS) is the most known and common dog breed of Turkey. It is almost not only spread all nationwide of Turkey, but also all over the world. TKnS is raised in all continentals except South America. Other dog breeds of Turkey are generally local breeds. The Turkish Akbash Shepherd (TAS) is located (Figure 1) in the Salt Lake region including provinces of Ankara, Afyon, Eskișehir and Manisa. The Kars (Caucasian) Shepherd (TKrS) and Dikkulak (Erect-ear) or Zagar (D/Z) dogs are mainly seen in the same region, east of Turkey (Tepeli et al. 2003; Yilmaz 2007a).

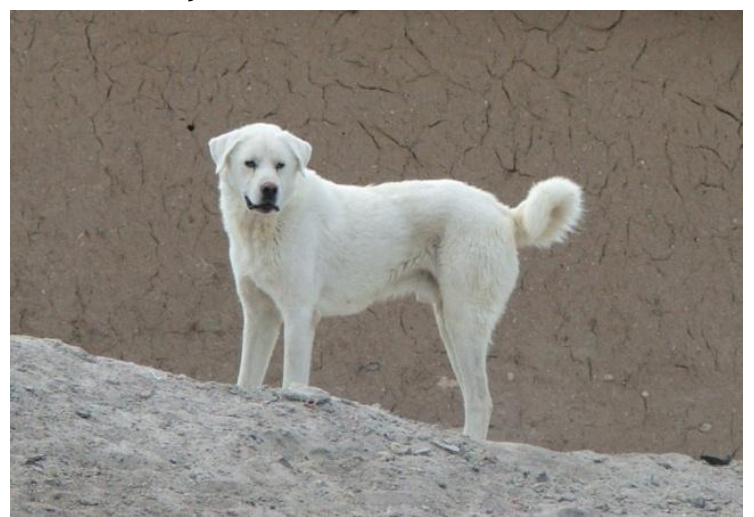

Figure 1. A good example of Turkish Akbash shepherd dog with cropped ears. 
Yılmaz \& Ertuğrul / BEU J SCI \& TECHNOL 2 (2012) 6-9

Table 1. Some morphological traits on various Turkish Breeds of dogs

\begin{tabular}{|c|c|c|c|c|c|c|c|}
\hline & Rt67 & HS (cm) & HR (cm) & BL (cm) & HGC (cm) & CD (cm) & $\mathrm{CC}(\mathrm{cm})$ \\
\hline TKnS* (Yilmaz 2007b) & 45.9 & 74.8 & 73.8 & 84.5 & 86.2 & 31.6 & 13.2 \\
\hline \multirow[t]{2}{*}{ TAS $^{*}\left(\right.$ TSE $\left.2002^{\mathrm{a}}\right)$} & $45-65(\precsim)$ & $60-85(ð))$ & & & & & \\
\hline & 35-55(q) & 50-75(웅 & & & & & \\
\hline TKrS* (Yilmaz \& Ertugrul 2012b) & 44.6 & 72.4 & 71.1 & 87.3 & 84.7 & 31.3 & 12.0 \\
\hline TT* (Yilmaz \& Ertugrul 2011ª) & 18.4 & 62.0 & 62.2 & 60.3 & 63.3 & 22.8 & 10.2 \\
\hline TC* (Yilmaz \& Ertugrul 2012b) & 21.7 & 48.5 & 48.5 & 49.1 & 64.0 & 20.8 & 10.5 \\
\hline D/Z* (Yilmaz \& Ertugrul 2011 b) & 10.6 & 27.8 & 29.1 & 46.3 & 50.9 & 21.8 & 9.5 \\
\hline
\end{tabular}

TKnS: Turkish Kangal (Shepherd), TAS: Turkish Akbas Shepherd, TKrS: Turkish Kars (Shepherd), TT: Turkis Tazi, TC: Tarsus Catalburun, D/Z: Dikkulak (erect-ear)/Zagar, LW: live weight, HS: height at shoulders, HR: height at rump, BL: body length, HGC: hearth girth circumferences, CD: chest depth, CC:cannon circumferences,

* There were no significant differences between means showed by the same letters of alphabet in the same line and factor group.

The Turkish Tazi (Sighthound) (TT) can be found in various provinces but it is mainly raised in Konya and Sanliurfa. The Tarsus Catalburun (Fork-nose) (TC) is a pointer type gun dog and only found in province of Icel. In province of Karaman and adjacent provinces there is a breed of Karaman Dog. In the northeast of Turkey there are also three local dog breeds on the north side of Canik Mountains. The first one is the Zerdava dog which is a working dog in medium size. The second one is Fino of Tonya, Trabzon. This breed is a small size toy dog. The last one is Rize Koyun (Sheep) dog which is another flock protection dog breed especially in provinces of Rize and adjacent provinces (Yilmaz 2006; Yilmaz 2007b; Yilmaz 2008; Yilmaz \& Ertugrul 2011a-c; Yilmaz \& Ertugrul 2012a-b).

TAS dog is a protecting dog with a flock of sheep and goat. This breed is not a herding dog. Main duty of TAS dog is to protect the flock, its owner/shepherd and his property from predators and to avoid intruders. The TAS dog has a strong body constitution. Only white coat colour can be seen. TAS dogs are very trustable, agile, healthy and tough dogs (Yilmaz 2007a; Yilmaz 2008). Although the Akbash dogs are primarily found in provinces of Ankara, Afyon, and Eskisehir which is called as "The Akbash Dog Triangle" they can also be found in other parts of Turkey such as Agri (Belli 2009), Sivas and Tunceli (pers. obs.). Sometimes The Akbash Dogs are thought as a colour variation of Kangal (Karabash) Dog, but Akbash is strictly a different breed unlike Kangal (Karabas) dogs (Koban et al 2003). In the literature there was only one study on Akbash dogs (Tepeli 2003).

The purpose of this study is to determine some phenotypic traits of TAS dogs by minding sex, region, age and coat colour factors by comparing with other dog breeds of Turkey.

\section{Material and Methods}

\subsection{Experimental Animals}

The Akbash Shepherd dogs in the study (Figure 2) were surveyed between April 2006 and September 2009 in the provinces of Afyon ( $38^{\circ} 46^{\prime} \mathrm{N}, 30^{\circ} 32^{\prime} \mathrm{E}$ ), Ankara $\left(39^{\circ} 56^{\prime} \mathrm{N}, 32^{\circ} 51^{\prime} \mathrm{E}\right)$, Eskișehir ( $\left.39^{\circ} 47^{\prime} \mathrm{N}, 30^{\circ} 31^{\prime} \mathrm{E}\right)$, and Manisa $\left(38^{\circ} 37^{\prime} \mathrm{N}, 27^{\circ} 25^{\prime} \mathrm{E}\right)$. A total of 59 dogs, 34 male and 25 female, were studied. The dogs were aged between 2 and 10 years, and divided into three age groups: 2-3 years, 4-5 years, and 6-10 years. In the first group there were 15 males and 7 females; in the second group there were 15 males and 9 females; and in the third group there were 4 males and 9 females. The ages of dogs were determined from the information given by their owners.

\subsection{Measurements}

The sampled dogs were weighed for live weight (LW) with a portable spring scale. Linear measures such as height at shoulders (HS), height at rump (HR), body length (BL), and chest depth (CD) were measured using a measuring stick calibrated in centimetres. Other linear measures such as hearth girth circumference (HGC), and cannon circumference (CC) were measured using a graduated plastic tape (Kirmizi 1991).

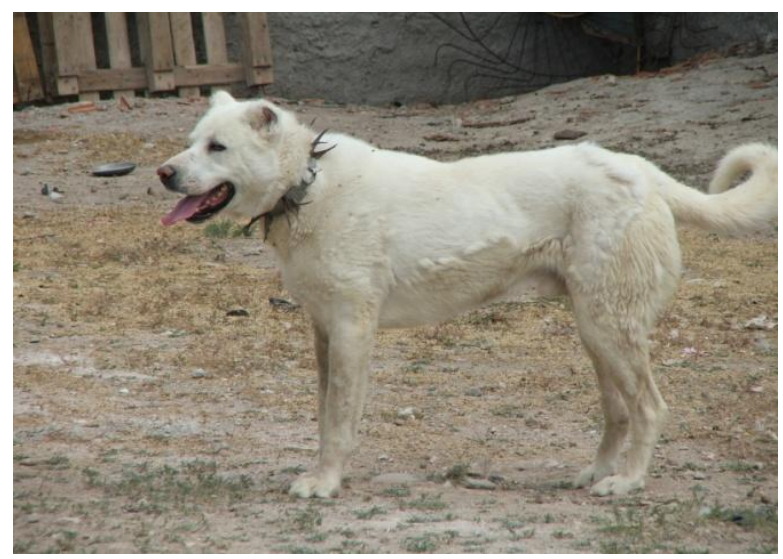

Figure 2. A juvenile Turkish Akbash shepherd dog

\subsection{Statistical Analysis}

The data obtained were analyzed using the Minitab 15 statistical software program. Descriptive statistics for body dimensions were analyzed using ANOVA and Student's T-Test that also determined the impact of sex, country and age group on the response variables of LW, $\mathrm{HS}, \mathrm{HR}, \mathrm{BL}, \mathrm{HGC}, \mathrm{CD}$, and CC.

\section{Results and Discussion}

As seen in Table 2 the effects of sex, region, age and coat colour on phenotypic traits were given. There were no significant differences for all morphological traits between male and females. Male dogs yielded higher values than females except for the traits of LW and CC. For those traits female dogs yielded higher values than males. In Table 2 the factors of region on live weight and body dimensions are also given. For the traits of HS, and HR the TAS dogs raised in province of Afyon was significantly different from the dogs raised in provinces of Ankara and Eskisehir $(\mathrm{P}<0.01)$. For the traits of $\mathrm{LW}$, and CD, the TAS dogs raised in provinces of Afyon and Manisa were significantly different from the dogs raised in province of Eskisehir $(\mathrm{P}<0.01)$. For the trait of CC the TAS dogs raised in the provinces of Eskisehir and Manisa 
Yılmaz \& Ertuğrul / BEU J SCI \& TECHNOL 2 (2012) 6-9

Table 2. Descriptive statistics and comparison results of the phenotypic traits of Turkish Akbash dogs for different sexes, regions and ages*

\begin{tabular}{|c|c|c|c|c|c|c|c|c|}
\hline & Traits & LW (kg) & HS (cm) & HR (cm) & BL (cm) & HGC (cm) & CD (cm) & CC (cm) \\
\hline \multirow[t]{3}{*}{ Sex } & Overall $(n=59)$ & $44.9 \pm 0.80$ & $75.3 \pm 0.59$ & $74.2 \pm 0.64$ & $81.8 \pm 1.00$ & $86.5 \pm 0.81$ & $32.6 \pm 0.33$ & $13.3 \pm 0.13$ \\
\hline & Male $(n=34)$ & $44.9 \pm 1.07$ & $75.9 \pm 0.84$ & $75.0 \pm 0.85$ & $82.6 \pm 1.46$ & $86.7 \pm 1.09$ & $32.6 \pm 0.42$ & $13.2 \pm 0.20$ \\
\hline & Female $(n=25)$ & $45.2 \pm 1.20$ & $74.4 \pm 0.78$ & $73.0 \pm 0.94$ & $80.6 \pm 1.29$ & $86.2 \pm 1.23$ & $32.5 \pm 0.55$ & $13.3 \pm 0.15$ \\
\hline \multirow[t]{4}{*}{ Region } & Ankara $(n=17)$ & $45.4 \pm 1.06^{\mathrm{ab}}$ & $76.5 \pm 0.83^{b}$ & $76.3 \pm 0.72^{b}$ & $82.5 \pm 1.18$ & $87.4 \pm 1.03$ & $32.5 \pm 0.61^{\mathrm{ab}}$ & $12.8 \pm 0.27^{\mathrm{A}}$ \\
\hline & Eskisehir $(n=22)$ & $48.8 \pm 1.31^{b}$ & $76.2 \pm 1.06^{b}$ & $74.9 \pm 1.06^{b}$ & $82.8 \pm 1.88$ & $87.7 \pm 1.58$ & $34.1 \pm 0.39 \mathrm{~b}$ & $13.6 \pm 0.20^{\mathrm{B}}$ \\
\hline & Afyon $(n=12)$ & $40.6 \pm 1.55^{a}$ & $72.0 \pm 1.22^{\mathrm{a}}$ & $70.2 \pm 1.67^{a}$ & $76.8 \pm 1.79$ & $83.0 \pm 1.84$ & $30.8 \pm 0.76^{a}$ & $13.0 \pm 0.16^{\mathrm{AB}}$ \\
\hline & Manisa $(n=8)$ & $40.3 \pm 0.37^{a}$ & $75.0 \pm 1.36^{\mathrm{ab}}$ & $73.8 \pm 1.25^{\mathrm{ab}}$ & $84.5 \pm 3.31$ & $86.3 \pm 1.70$ & $31.2 \pm 0.65^{\mathrm{a}}$ & $13.6 \pm 0.36^{\mathrm{B}}$ \\
\hline \multirow[t]{3}{*}{ Age } & $2-3(n=22)$ & $44.7 \pm 0.75$ & $75.8 \pm 0.75^{\mathrm{B}}$ & $74.5 \pm 0.78$ & $83.3 \pm 1.49$ & $86.3 \pm 1.14 \mathrm{AB}$ & $33.1 \pm 0.40$ & $13.0 \pm 0.22$ \\
\hline & $4-5(n=24)$ & $46.5 \pm 1.56$ & $76.3 \pm 1.01^{\mathrm{B}}$ & $75.3 \pm 1.02$ & $82.8 \pm 1.77$ & $88.7 \pm 1.24^{\mathrm{B}}$ & $32.5 \pm 0.61$ & $13.5 \pm 0.23$ \\
\hline & $6-10(n=13)$ & $42.6 \pm 1.66$ & $72.5 \pm 1.20^{\mathrm{A}}$ & $71.4 \pm 1.61$ & $78.9 \pm 1.86$ & $82.7 \pm 1.76^{A}$ & $31.8 \pm 0.74$ & $13.1 \pm 0.14$ \\
\hline
\end{tabular}

LW: live weight, HS: height at shoulders, HR: height at rump, BL: body length, HGC: hearth girth circumference, CD: chest depth, CC: cannon circumference. There were no significant differences between means showed by the same letters of alphabet in the same line and factor group a, $\mathrm{P}<0.01, \mathrm{~A}, \mathrm{~B}: \mathrm{P}<0.05$

were significantly different from the dogs raised in province of Ankara $(\mathrm{P}<0.05)$. For the factor of age, the descriptive statistics and comparison results are also given in Table 2 . Among the three age groups, the oldest dog group of 6-10 year-old TAS dogs were significantly different from the group of 2-3 and 4-5 year-old dogs for the trait of HS, and 4-5 year old dogs for the traits of HGC $(\mathrm{P}<0.05)$. After 1 year, there was minor difference for all traits until 6 years of age. It can be concluded that the TAS dogs grow up to 2 years of age, and after that there is only minor growth. The oldest dog group yielded lower values than the younger dogs, but it did not mean that dogs lost weight after 5 years of age. One possibility might be that males were the majority in the two younger age group but females were the majority in the oldest dog group, therefore, the values were smaller in body dimensions.

The results obtained in this study (Table 2) were compared with other native dog breeds of Turkey (Table 1). The results showed that the TAS, TKnS and TKrS dogs were almost similar for all traits of body dimensions. But the value of BL was smaller than the other two breeds. It shows that TAS has a more compact body structure than the other two breeds. With regard to other small dog breeds of Turkey, TAS dogs were twice heavier than TT, $\mathrm{TC}$ and four times heavier than $\mathrm{D} / \mathrm{Z}$ dogs for the trait of live weight. For other traits of HS, HR, BL, HGC, CD and $\mathrm{CC}$, the observed values of TAS were higher than results of TT, TC, and D/Z dogs. This study values were compared to the values of Tepeli. For the traits of LW, HS, HR, BL, and HGC this study values were higher than the values of Tepeli (Table 1 and 2). The values of Tepeli were belonged to 1 year-old age Akbash dogs, therefore values of Tepeli might be lower than this study values.

This breed has been started to be used as a livestock guarding dog since 1970s in USA (Coppinger et al 1996, Green and Woodruff 1996). The population number of this breed in USA was about 1.500 as registered Akbash Dogs in 1996. All Akbash Dogs were registered under the Akbash Dog Association of America (ASDA) which was established in 1979. This number might be more in this time (Taylor 1996).

At the present time there is no Akbash Shepherd Dog Club or Association in Turkey but in USA. The Akbash dog is one the genetic resources of Turkey and its number decreases year by year. It is possible that the current population number of Akbash Dogs in USA is more than in Turkey.
Table 3. Phenotypic correlation coefficient values (r) among body measurements in TAS dogs.

\begin{tabular}{lllllll}
\hline Traits & LW & HS & HR & BL & HGC & CD \\
\hline HS & $0.67^{* *}$ & & & & & \\
HR & $0.70^{* *}$ & $0.92^{* *}$ & & & & \\
BL & $0.46^{* *}$ & $0.82^{* *}$ & $0.74^{* *}$ & & & \\
HGC & $0.65^{* *}$ & $0.81^{* *}$ & $0.79^{* *}$ & $0.65^{* *}$ & & \\
CD & $0.74^{* *}$ & $0.46^{* *}$ & $0.48^{* *}$ & $0.33^{*}$ & $0.44^{* *}$ & \\
CC & $0.35^{* *}$ & $0.39^{* *}$ & $0.41^{* *}$ & $0.44^{* *}$ & $0.36^{* *}$ & 0.15 \\
\hline
\end{tabular}

${ }^{*} \mathrm{P}<0.05,{ }^{* *} \mathrm{P}<0.01$

The phenotypic correlation coefficient values summarized in the Table 3 show that almost all observed traits were affected by the others. The highest value was found between HS and HR $(r=0.92)(P<0.01)$. The other highest values were found between HS and BL $(r=0.82)$, HS and HGC $(r=0.81)$, HR and HGC $(r=0.79)$, LW and CD $(\mathrm{r}=0.74)(\mathrm{P}<0.01)$. The correlations of LW-HS, LW-HR, LW-HGC, HR-BL, and BL-HGC also yielded higher values $r$ $=0.50(\mathrm{P}<0.01)$. The lowest value $(\mathrm{r}=0.30)$ was found between $B L$ and $C D(P<0.05)$. The other low correlation values were found between HR-CD $(r=0.48)$, LW-BL $(r=$ 0.46), HS-CD ( $r=0.46)$, BL-CC $(r=0.44)$, HGC-CD ( $r=$ $0.44)$, HR-CC $(r=0.41)$, HS-CC $(r=0.39)$, HGC-CC $(r=$ $0.36)$, and LW-CC $(r=0.35)(P<0.01)$. There were no significant correlation between the traits of CD-CC and negative correlation among all traits as seen in Table 3.

\section{Conclusion}

It can be concluded that Turkish Akbash Shepherd dog is a big size livestock protection dog breed of Turkey. The overall results of the current study demonstrated that Turkish Akbash Shepherd dogs had a very close resemblance to the other livestock protection dog breeds of TKnS and TKrS raised in Turkey. These dogs grow up to 2 years of age and after then there is only minor growth. It can be said that Turkish Akbash Shepherd dog reaches mature body weight and size at around 2 years of age. In USA the ASDA was established in 1979 but in Turkey there was no club or association related with this breed. As Turks we should congratulate both Akbash Dog breeders and board of directors of ASDA in USA because of being aware of majestic value of this breed. We should appreciate and save this breed for generations. 


\section{Acknowledgements}

This study was carried out under the supervision of Prof. Dr. Mehmet Ertugrul (Ankara University, Turkey) and the first author gratefully thanks him. The authors would also like to thank Prof. Dr. Firat Cengiz (Yuzuncu Yil University), Prof. Dr. Ensar Baspinar (Sinop University), Prof. Dr. Ibrahim Zafer Arik (Akdeniz University), Prof. Dr. Saim Boztepe (Selcuk University), Prof. Dr. Askin Kor (Yuzuncu Yil University) and Assoc. Prof. Dr. Yalcin Bozkurt (Suleyman Demirel University) for their constructive comments and for editing in English.

\section{References}

Belli O (2006). Anadolu ve dünyanın en eski avcı köpek resimleri. Av ve Doğa Derg 17-18 pp.

Belli O (2009). Yeni keşfedilen Urartu sulama tesisleri (2003-2008). II. International symposium of Mount Ararat and Noah's Ark., 12-34 pp., 8-10 October 2008, Doğubeyazıt, Ağrı, Turkey.

Clutton-Brock J (1995). Origins of the dog: Domestication and early history. The domestic dog, its evolution, behaviour and interactions with people. In: Serpell (ed.), published by Cambridge University Press, 7-20 pp.

Coppinger R, Coppinger L, Harned M (1996). The importance of dogs in guarding the flocks in the USA. Uluslararasi Turk Coban Kopegi Sempozyumu, 171196 pp., 23 Ekim 1996, Konya, Turkiye.

Green JS, Woodruff RA (1996). Livestock guarding dogs and predation management: 19 years of effort by the U.S. Uluslararası Türk Çoban Köpeği Sempozyumu, 197-216 pp., 23 Ekim 1996, Konya, Turkiye.

Kırmızı E (1991). Türk çoban köpekleri ve Alman çoban köpeklerinin dölverimi, büyütülen yavru oranı, büyüme ve beden ölçüleri yönünden karşılaştırılması. Institute of Health Sciences, Ph.D Thesis, İstanbul University, pp 114.

Koban E, Altunok, V, Nizamlıoğlu M, Togan İ (2003). Employment of some molecular techniques to answer some questions and problems related with Kangal dog. Ist International Symposium of Kangal Dog, 83-88 pp., 11 July 2003, Kangal-Sivas, Turkey.

Pugnetti G (2001). Köpek ansiklopedisi. Arkadaş Yayınları, Ankara.

Savolainen P, Zhang YP, Luo J, Lundeberg J, Leitner T (2002). Genetic evidence for an east Asian origin of dogs. Science 298, 1610-1613.

Serpell JA (1996). The origin of dogs. Uluslararası Türk Çoban Köpeği Sempozyumu, 7-18 pp., 23 Ekim 1996, Konya-Turkey.

Sims DE, Dawydiak 0 (1990). Livestock protection dogs Selection, care and training. OTR Publications. Alabama, USA, $240 \mathrm{p}$.

Taylor T (1996). Breeding Turkish shepherd dogs in the U.S. Uluslararası Türk Çoban Köpeği Sempozyumu, 147-170 pp., 23 Ekim 1996, Konya, Turkiye.

Tepeli C (2003). Kangal ve Akbaş ırkl Türk çoban köpeklerinde büyüme özellikleri. Türk Vet Hay Derg 27, 1011-1018.

Tepeli C, Çetin O, Günlü A, Kırıkçı K (2005). The native dog breeds of Turkey. EAAP Publication, No 115, Wageningen Academic Publishers, 427-431 pp.
TSE (2002). Damızlık hayvanlar - Akbaș Türk Çoban köpeği. Türk Standartları Enstitüsü, No: 11471, TS 12891, Ankara.

Yılmaz 0 (2006). Sürü koruyucu köpek ırkları. Institute of Science and Technology, Ph.D Seminar, Ankara University, $82 \mathrm{pp}$.

Yılmaz O (2007a). Turkish Kangal (Karabash) Shepherd dog. Impress Printing Comp. Ankara, 148 p.

Yılmaz O (2007b). Türkiye'nin çeșitli bölgelerinde yetiştirilmekte olan Kangal köpeklerinin bazı morfolojik özellikleri. Institute of Science and Technology, Ph.D Thesis, Ankara University, 262 p.

Yılmaz 0 (2008). Türk Kangal (Karabaş) Çoban köpeği. Bilge Kültür Sanat Yayınevi, İstanbul.

Yılmaz 0, Ertuğrul M (2011a). Some morphological characteristics of Turkish Tazi (Sighthound). J Anim Plant Sci 21, 794-799.

Yllmaz 0, Ertuğrul, M (2011b). Some morphological traits of the Zağar (erect-ear) dog in Turkey. Igdir Univ Fen Bil Enst Derg 1, 107-112.

Yılmaz 0, Ertuğrul M (2011c). Spread story of Kangal (Karabash) shepherd dogs in the World. Iğdır Univ Fen Bil Enst Derg 1, 117-120.

Yılmaz 0, Ertuğrul M (2012a). Determination of Koyun dog. Canadian J Appl Sci 2, 216-221.

Yilmaz 0, Ertugrul M (2012b). Some morphological characteristics of the Tarsus Fork-nose dog in Turkey. Bulgarian J Agric Sci Bulgaria 18, 111-115. 